\title{
00R-IASIO0
}

Available online at Website http://ejournal.undip.ac.id/index.php/rotasi

\section{EFEK LOKASI INJEKTOR TERHADAP INDEKS PENCAMPURAN AMMONIA UNTUK SCR DENGAN MIXER DINAMIK}

\author{
*Syaiful, Iseu Andriani \\ Jurusan Teknik Mesin, Fakultas Teknik, Universitas Diponegoro \\ Jl. Prof. Sudarto SH, Tembalang, Semarang \\ *E-mail: syaiful.undip2011@gmail.com
}

\begin{abstract}
Diesel engines many are used as transportation mode in the land and sea compared with gasoline engines due to their high efficiency and durability. However, diesel engine releases much more NOx and soot emissions than that of gasoline engine. NO $O_{x}$ is formed from a reaction of Nitrogen and Oxygen at high temperature. If these emissions are breathed into human body resulting respiratory disorders such as emphysema and bronchitis as well as lungs tissue damage. Therefore, $N O_{x}$ emissions controll is required to reduce them reaching under a threshold level. An effective method for controlling $\mathrm{NO}_{x}$ emissions produced by the diesel engines is by injecting ammonia obtained from urea into selective catalytic reduction (SCR method) system. Ammonia by means of catalyst reacts with NOx forming Nitrogen $\left(\mathrm{N}_{2}\right)$ and Water $\left(\mathrm{H}_{2} \mathrm{O}\right)$. Therefore, a chance of each ammonia particle to react with each $\mathrm{NO}_{x}$ particle is required to consider. A reaction quality between ammmonia and $\mathrm{NO}_{x}$ particles can be increased by improving a mixing index. One of the methods to increase the mixing index is by using a dynamic mixer.There are several factors which influence the increase of mixing index. One of these factors is a location of ammonia injector. Since this work is focused on investigating the effect of ammonia injector location on the mixing index of ammonia to diesel engine exhaust gases which content of $\mathrm{NO}_{x}$ emissions.
\end{abstract}

Keywords: Diesel engines, NOx emissions, Ammonia-SCR system, Ammonia injector location, Mixing index

\section{PENDAHULUAN}

Pencemaran udara di Indonesia sungguh sangat memprihatinkan. Berdasarkan laporan penelitian yang dilakukan oleh World Bank, Jakarta ditempatkan pada kota yang memiliki kadar polutan tertinggi di dunia setelah Beijing dan New Delhi [1]. Sektor transportasi merupakan penyumbang terbesar polusi udara [2]. Penggunaan mesin diesel sebagai moda transportasi darat dan laut semakin meningkat oleh karena efisiensi dan ketahanan mesin yang tinggi jika dibandingkan dengan mesin bensin. Akan tetapi mesin diesel memiliki permasalahan yang signifikan menyangkut emisi NOx dan jelaga yang dilepaskan ke udara. Oleh karena itu tantangan yang cukup besar dalam penggunaan mesin diesel adalah pengontrolan emisi NOx dan jelaga. Seperti yang telah dilakukan oleh Andreas Hinz dkk [3], mereka mencoba menggabungkan metode DPF (Diesel Particulate Filter) dan Urea-SCR (Selective Catalytic Reduction) untuk mereduksi berturut-turut emisi jelaga dan $\mathrm{NO}_{\mathrm{x}}$ dari mesin diesel. Penelitian ini difokuskan pada salah satu cara untuk mereduksi NOx yaitu dengan menggunakan metode SCR. Metode ini menggunakan Ammonia (NH3) sebagai pereduktor melalui katalis. $\mathrm{NH}_{3}$ diperoleh dari urea cair untuk faktor keamanannya. Urea cair inilah yang disemprotkan di depan SCR oleh karena proses pirolisis maka akan diperoleh $\mathrm{NH}_{3}$.

Ada banyak penelitian yang menggunakan metode ini, seperti yang dilakukan oleh Joseph dan Erdogan [4]. Bahkan mereka menggabungkan metode LNT (Lean $\mathrm{NO}_{\mathrm{x}}$ Trap), yang merupakan salah satu metode untuk mereduksi $\mathrm{NO}_{\mathrm{x}}$ juga, dengan metode SCR. Pada penelitian mereka, urea yang terlarut di dalam air diinjeksikan dibelakang LNT dan di depan SCR. Banyak hal yang perlu diperhatikan ketika menggunakan sistem urea-SCR untuk mengontrol $\mathrm{NO}_{\mathrm{x}}$, seperti temperatur di permukaan katalis dan ketika katalis tidak aktif. Hal ini telah dipelajari oleh Hisakazu S. dan Hajime I yang mana mereka meneliti karakteristik emisi $\mathrm{NO}_{\mathrm{x}}$ dan particulate matter ketika SCR tidak aktif atau tidak berfungsi [5]. Permasalahan yang tak kalah penting dengan penggunaan sistem urea-SCR adalah masalah pencampuran yang sempurna antara partikel ammonia dan partikel $\mathrm{NO}_{\mathrm{x}}$ di permukaan katalis. Oleh karena itu Mikael Karlsson dkk. mempelajari melalui pemodelan desain mixer dengan membandingkan perbedaan temperatur disekitar permukaan katalis [6]. Dari pemodelan ini, Karlsson dkk. mampu memperlihatkan pola aliran dari gas buang, injeksi dan pencampuran larutan urea di dalam aliran gas buang serta mekanisme termodinamikanya. Analisis yang lebih mendalam tentang injeksi urea dan proses yang terjadi di dalam aliran gas buang dipelajari oleh Felix Birkhold dkk [7]. Mereka mempelajari efek dari spray impact pada dinding permukaan pipa kenalpot. Sedangkan karakteristik pencampuran $\mathrm{NH}_{3}$ di dalam aliran gas buang di depan SCR telah diteliti melalui metode numerik oleh Xiaogang Z. dkk. [8]. Mereka telah mengamati efek penggunaan mixer jenis delta wing terhadap indeks pencampuran $\mathrm{NH}_{3}$ di dalam aliran gas buang sebelum SCR. Bahkan mereka juga telah mempelajari efek dari jenis mixer dan jumlah blade dari mixer terhadap indeks pencampuran. 
Berdasarkan studi literatur diatas terdapat beberapa parameter yang perlu untuk dipertimbangkan dalam mempelajari penggunaan sistem urea-SCR untuk menurunkan emisi $\mathrm{NO}_{\mathrm{x}}$ yang dihasilkan dari mesin diesel. Oleh karena itu, penelitian ini memfokuskan untuk mempelajari secara numerik efek lokasi injektor $\mathrm{NH}_{3}$ terhadap indeks pencampuran serta membanndingkan antara mixer dinamik dan statik dengan tanpa menggunakan mixer relevansinya terhadap indeks pencampuran pada sistem $\mathrm{NH}_{3}$-SCR.

\section{METODOLOGI}

Model yang dikaji dalam penelitian ini berupa saluran knalpot dengan SCR di dalamnya seperti skema yang ditunjukkan pada Gambar 1. Dari skema tersebut dapat diperlihatkan beberapa lokasi injektor dan lokasi mixer yang menjadi fokus pada penelitian ini. Dua injektor diletakkan pada jarak $3 \mathrm{~cm}$ dan $8 \mathrm{~cm}$ di depan mixer dan dua injektor lainnya diletakkan $3 \mathrm{~cm}$ dan $8 \mathrm{~cm}$ di belakang mixer. SCR berupa honeycomb yang diletakkan pada jarak $48 \mathrm{~cm}$ dari lokasi mixer. Inlet diletakkan jauh dari mixer untuk mendapatkan pola aliran yang berkembang penuh. Hal ini dilakukan untuk menghindari adanya aliran balik dari gas di dalam saluran. Gambar 3-D untuk sistem $\mathrm{NH}_{3}-\mathrm{SCR}_{\text {pada }}$ penelitian ini dapat ditunjukkan pada Gambar 2.

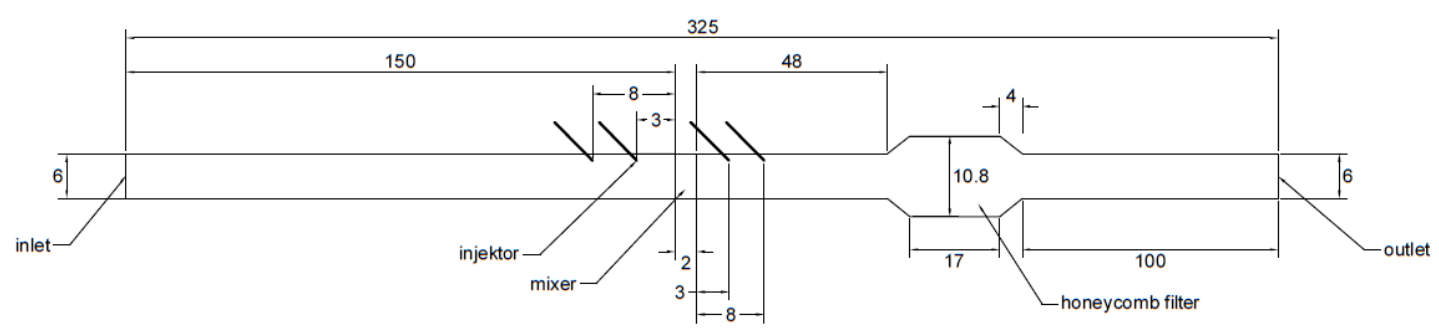

Gambar 1. Skema model saluran knalpot dengan sistem SCR.

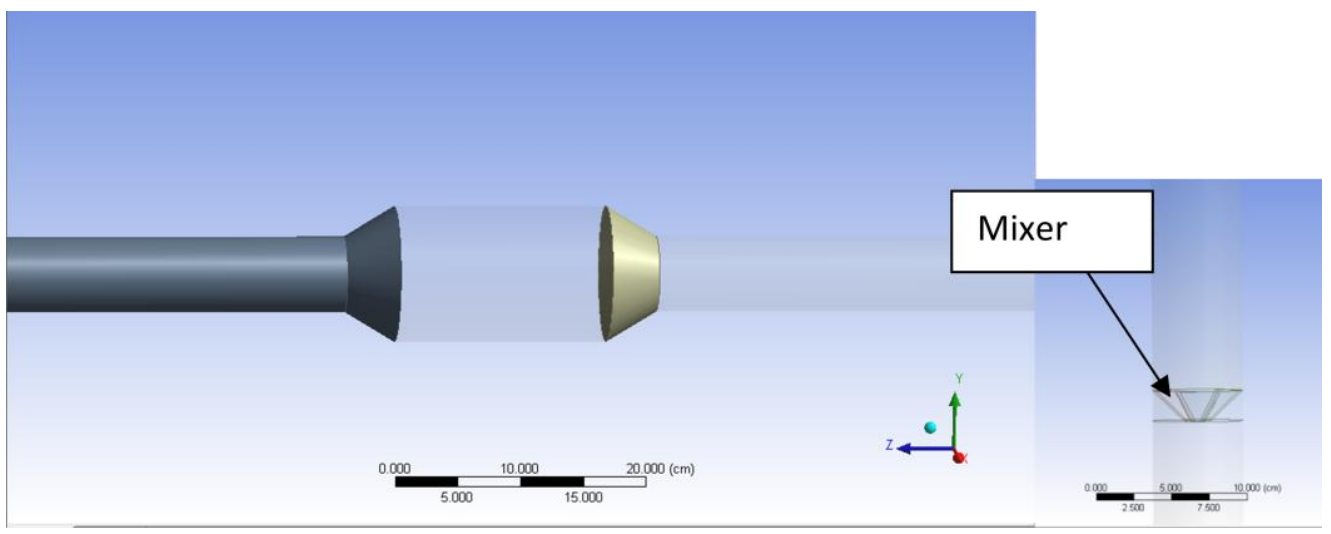

Gambar 2. Gambar 3-D sistem $\mathrm{NH}_{3}-\mathrm{SCR}$ pada knalpot

Penggenerasian mesh dilakukan pada sistem $\mathrm{NH}_{3}$-SCR dengan membagi daerah mesh menjadi dua jenis seperti yang ditunjukkan pada Gambar 3. SCR diasumsikan sebagai media berpori dalam pemdelan. Untuk saluran pipa di depan SCR dimana lokasi mixer berada digunakan jenis mesh tetahedral sedangkan daerah SCR dan dibelakangnya digunakan mesh jenis hexahedral. Hal ini dilakukan oleh karena kerumitan desain oleh karena adanya mixer.

Pemodelan numerik untuk sistem $\mathrm{NH}_{3}$-SCR dilakukan dengan mengasumsikan gas buang mesin diesel sebagai udara panas pada temperatur $450 \mathrm{~K}$ oleh karena tidak dianalisisnya reaksi kimia yang terjadi di dalamnya. $\mathrm{NH}_{3}$ yang diinjeksikan berfasa gas dengan temperatur 300K. Perhitungan numerik dilakukan pada keadaan steady dengan fluida incompressible. Berdasarkan uji grid independen, jumlah mesh untuk sistem $\mathrm{NH}_{3}-\mathrm{SCR}$ dalam penelitian ini adalah 89.183. Model turbulen yang dipilih adalah model standar $k-\varepsilon$ dengan perlakuan fluida dekat dinding menggunakan standard wall function. Deskretisasi persamaan momentum dan energi menggunakan upwind differencing scheme. Distribusi kecepatan dan tekanan pada pemodelan dipecahkan dengan menggunakan metode SIMPLE. Sifat-sifat fisik dari fluida merupakan fungsi polinomial dari temperatur oleh karena adanya pencampuran dua zat yang berbeda temperaturnya.

Kondisi batas di inlet disusun dengan mengasumsikan kecepatan seragam, dimana:

$\boldsymbol{u}=$ konstan,$v=w=0$ 


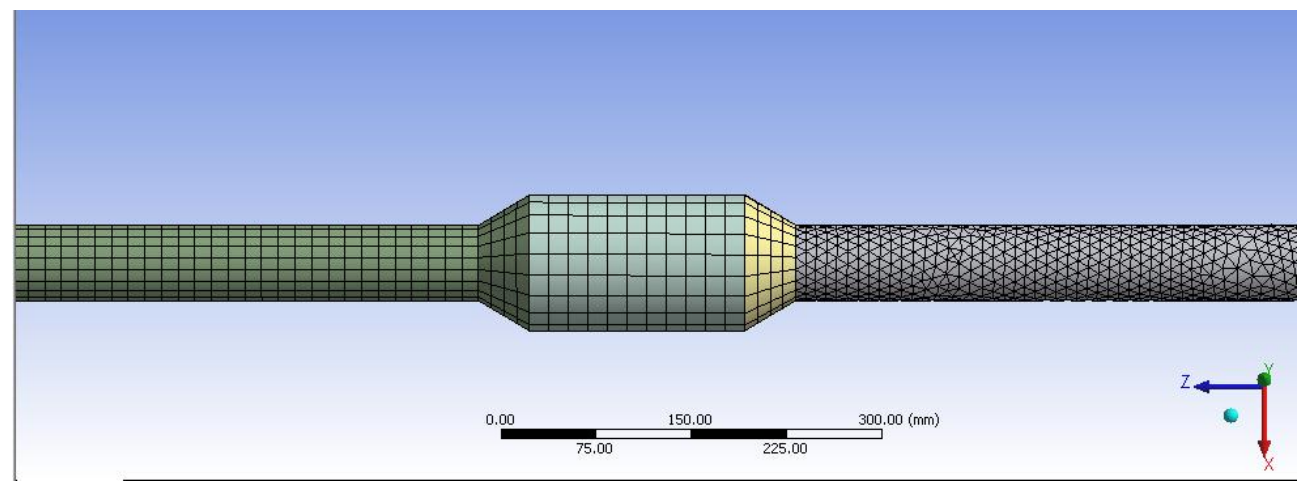

Gambar 3. Model grid pada domain komputasi sistem $\mathrm{NH}_{3}-\mathrm{SCR}$.

Kecepatan di dalam sistem $\mathrm{NH}_{3}$-SCR untuk aplikasi mesin diesel dinyatakan dalam GHSV (Gas Hourly Space Velocity), yaitu laju aliran volume dibagi volume katalis. Temperatur di sisi inlet dibuat konstan $450 \mathrm{~K}$.

$T_{\text {inlet }}=$ Konstan

Intensitas turbulen dihitung dengan menggunakan Persamaan 4 berikut,

$I \equiv \frac{u^{\prime}}{u_{\text {avg }}}=0.16 \mathrm{Re}^{-\frac{1}{8}}$

Kondisi batas dinding diasumsikan no-slip yang berarti kecepatan fluida di dinding sama dengan nol.

$\boldsymbol{u}=\boldsymbol{v}=\boldsymbol{w}=\mathbf{0}$ dan $\boldsymbol{T}_{\text {dinding }}=$ Konstan

Kondisi batas di sisi outlet ditetapkan dengan mengikuti kondisi batas Newmann. Dinding mixer didefinisikan sebagai moving wall. Domain mixer didefinisikan sebagai frame yang bergerak (moving reference frame). Laju aliran masa $\mathrm{NH}_{3}$ yang diinjeksikan berdasarkan jumlah $\mathrm{NO}_{\mathrm{x}}$ yang dilepaskan oleh mesin diesel tertentu. Untuk mendapatkan perhitungan yang valid, nilai friction coefficient yang diperoleh dari hasil pemodelan sepanjang pipa bagian depan tanpa mixer dibandingkan dengan hasil teori dan eksperimen yang sudah ada seperti yang diperlihatkan pada Gambar 4.

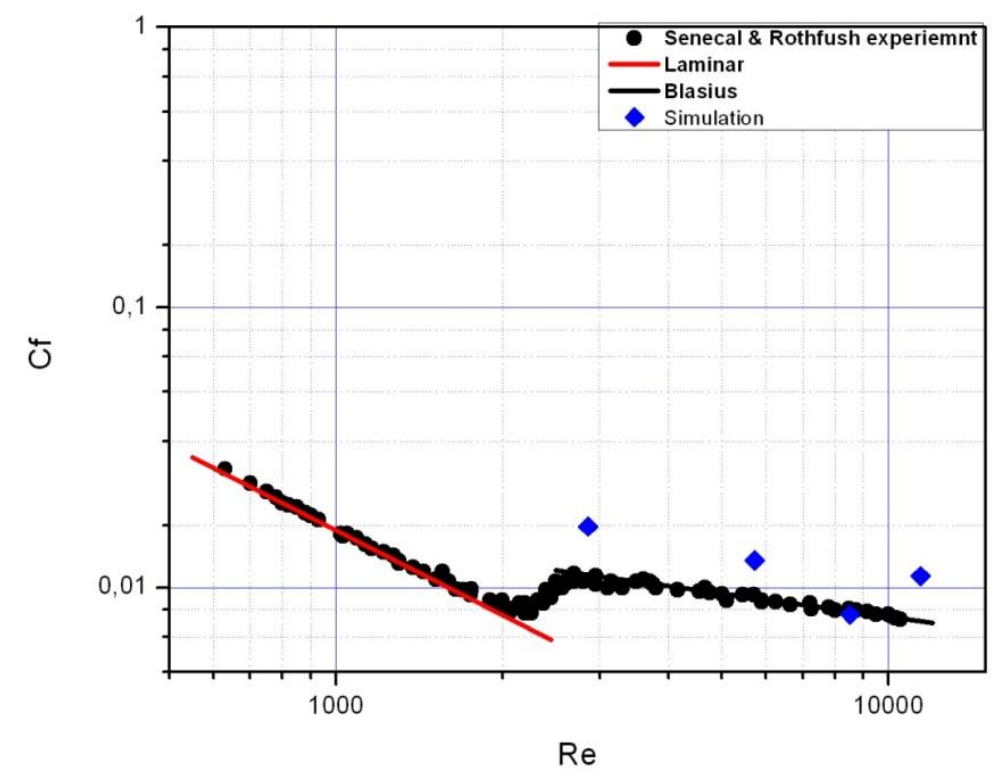

Gambar 4. Perbandingan friction coefficient antara hasil simulasi dengan eksperimen Senecal dan Rothfush serta hasil teori dari kasus laminar dan Blasius 


\section{HASIL DAN PEMBAHASAN}

Untuk mengetahui keseragaman $\mathrm{NH}_{3}$ di dalam aliran gas buang pada sistem $\mathrm{NH}_{3}-\mathrm{SCR}$ dapat diindikasikan dengan menggunakan indeks pencampuran yang dapat ditunjukkan pada Persamaan 5 berikut:

$\Gamma=1-\frac{\int_{A_{0}}\left|C-C_{0}\right| d A}{2 A_{0} C_{0}}$ dan $C_{0}=\frac{\int_{A_{0}} C d A}{A_{0}}$

dimana $\Gamma$ adalah indeks pencampuran, $\mathrm{C}$ adalah konsentrasi masa $\mathrm{NH}_{3}$ di daerah tertentu dalam sebuah penampang, sedangkan $\mathrm{C}_{0}$ adalah jumlah konsentrasi ammonia di penampang. A dan $\mathrm{A}_{0}$ adalah berturut-turut luas penampang dimana jumlah tertentu konsentrasi $\mathrm{NH}_{3}$ terdapat dan luas penampang total. Nilai indeks pencampuran ini berada pada rentang antara 0 sampai 1.0 berarti $\mathrm{NH}_{3}$ terdistribusi di satu titik di dalam penampang, sedangkan 1 berarti $\mathrm{NH}_{3}$ terdistribusi merata di penampang. Hal ini berarti bahwa indeks pencampuran mendekati 1 , $\mathrm{maka} \mathrm{NH}_{3}$ bercampur sempurna di dalam aliran gas buang. Gambar 5 menunjukkan perbandingan indeks pencampuran antara sistem $\mathrm{NH}_{3}-$ SCR yang menggunakan mixer dinamik dengan yang tanpa penggunakan mixer untuk berbagai lokasi injektor yang berbeda dengan nilai GHSV dari 10.000 sampai 40.000 .

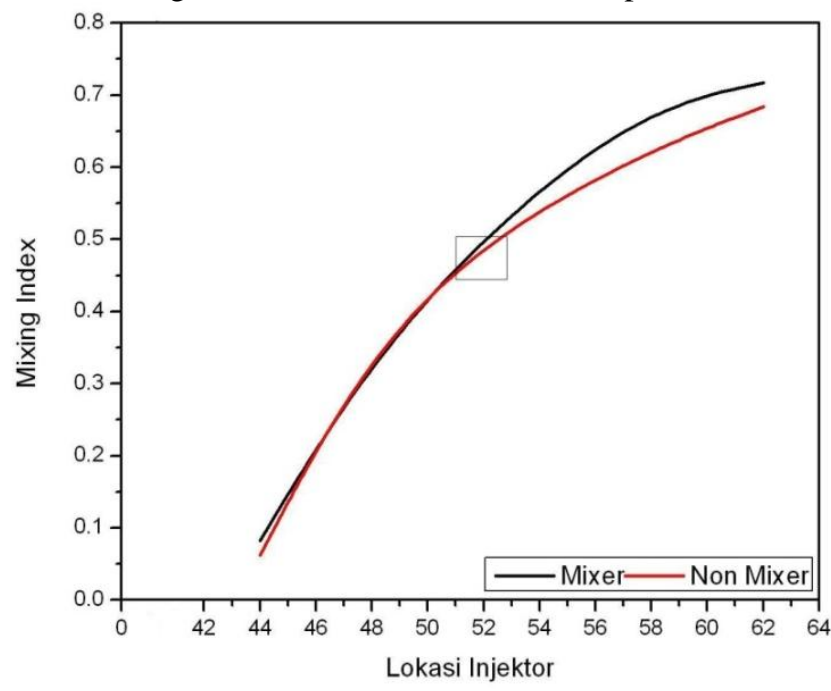

(a) GHSV 10.000

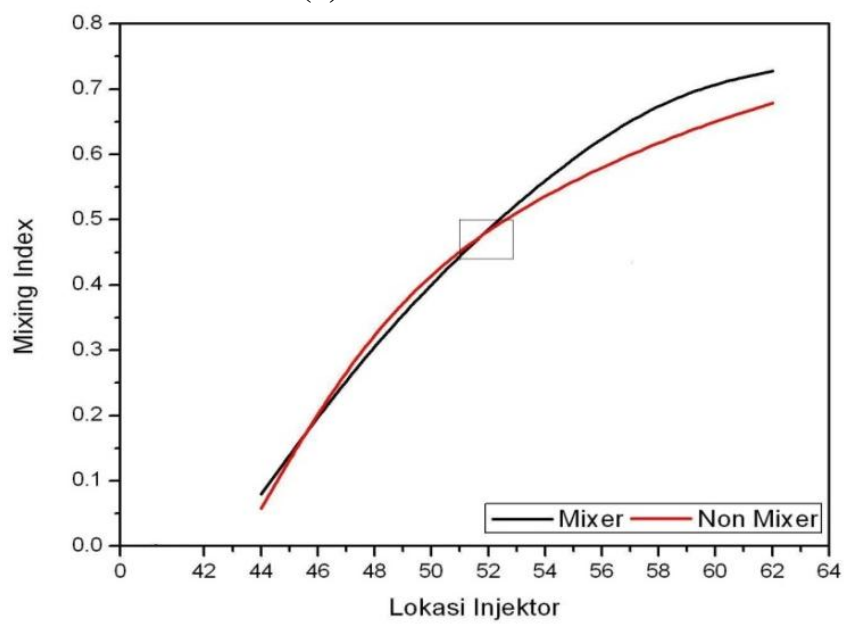

(c) GHSV 30.000

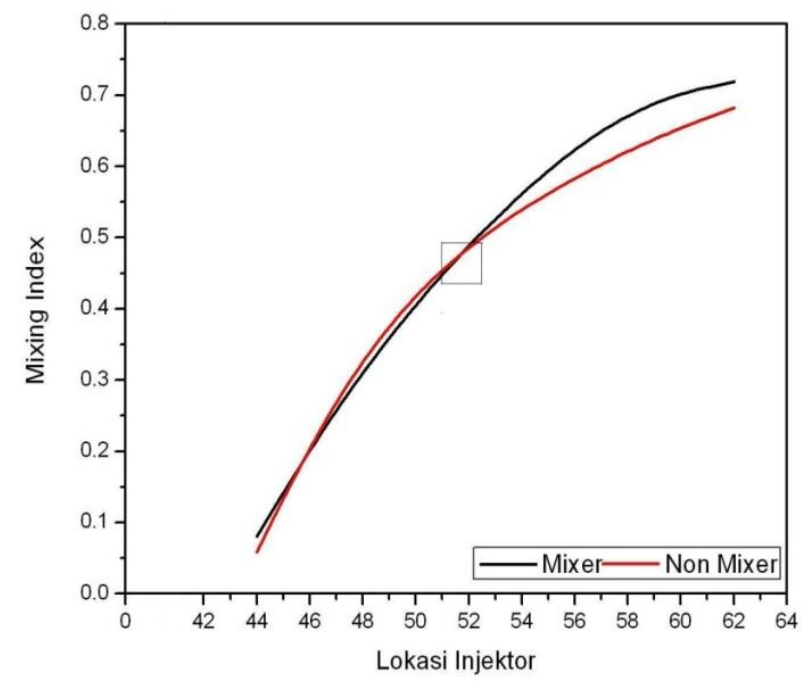

(b) GHSV 20.000

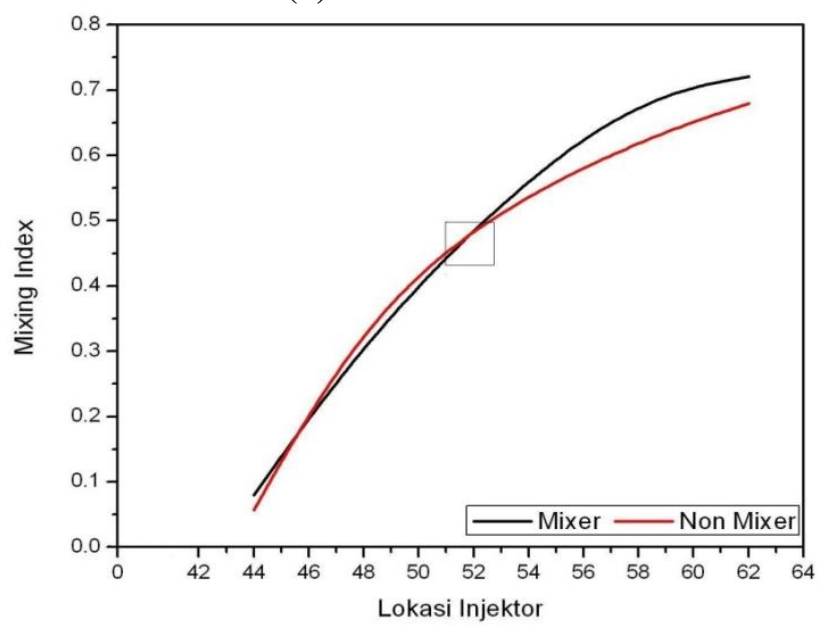

(d) GHSV 40.000

Gambar 5. Perbandingan indeks pencampuran (mixing index) antara sistem $\mathrm{NH}_{3}$-SCR yang menggunakan mixer dinamik dengan yang tanpa menggunakan mixer untuk lokasi injektor yang berbeda pada berbagai variasi GHSV

Dari Gambar 5 dapat diamati bahwa penggunaan mixer dinamik menghasilkan indeks pencampuran yang lebih tinggi untuk injektor yang diletakkan di depan mixer pada semua GHSV. Sebaliknya, penggunaan mixer dinamik tidak berpengaruh terhadap indeks pencampuran apabila injektor diletakkan setelah mixer untuk semua nilai GHSV.

Dalam penelitian ini juga dibandingkan nilai indeks pencampuran antara sistem NH3-SCR yang menggunakan mixer dinamik dan mixer statik serta yang tanpa menggunakan mixer seperti yang ditunjukkan pada Gambar 6 . 


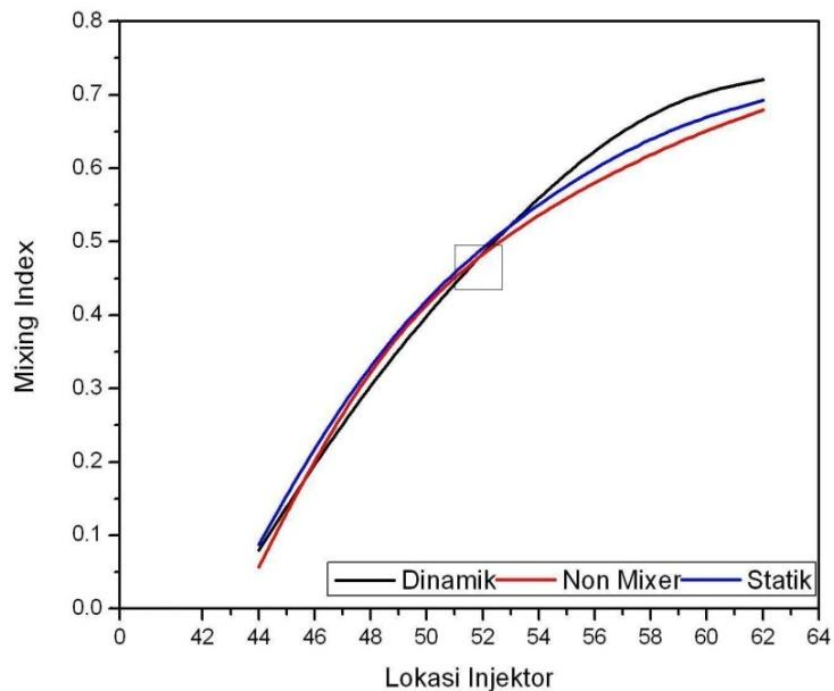

(a) GHSV 10.000

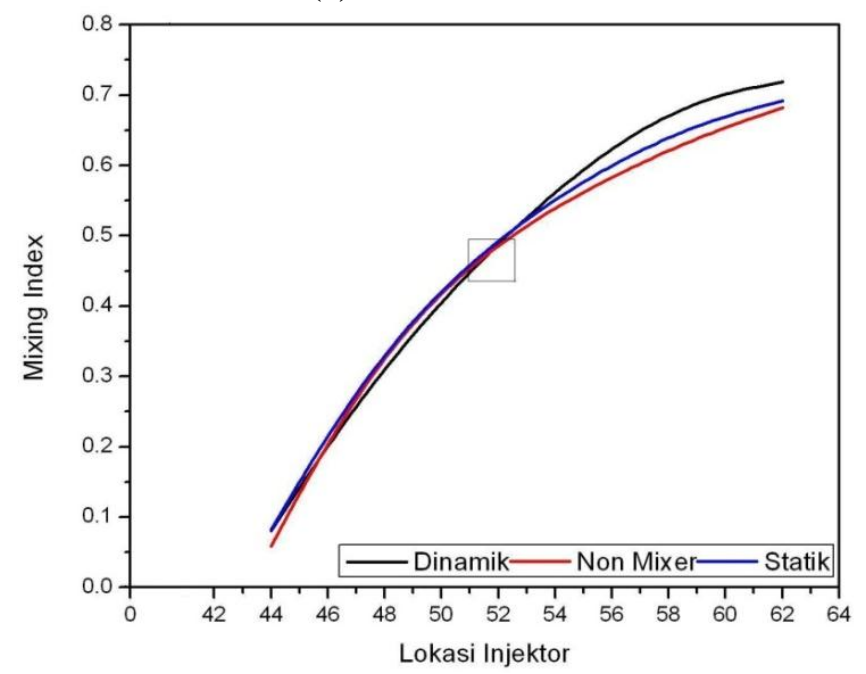

(c) GHSV 30.000

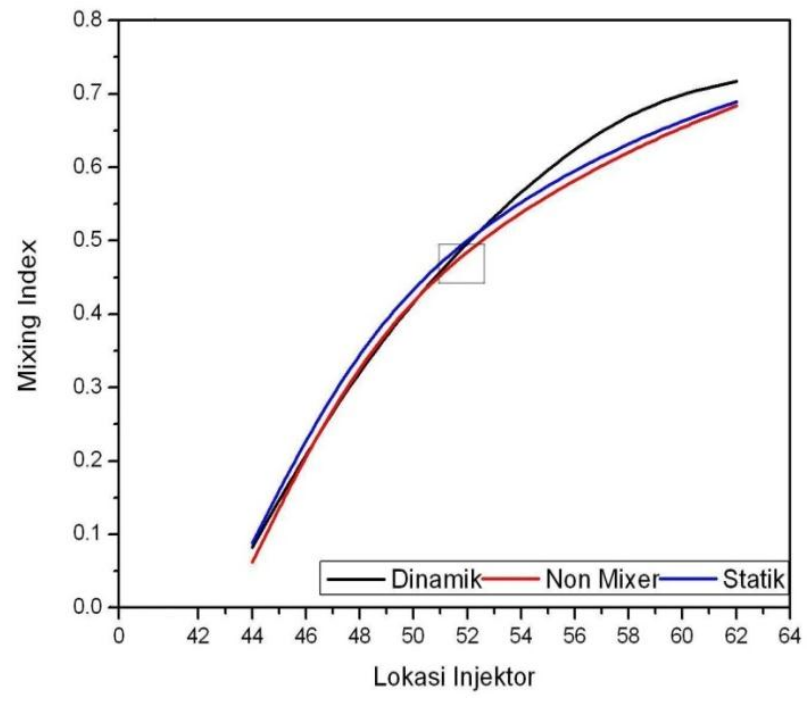

(b) GHSV 20.000

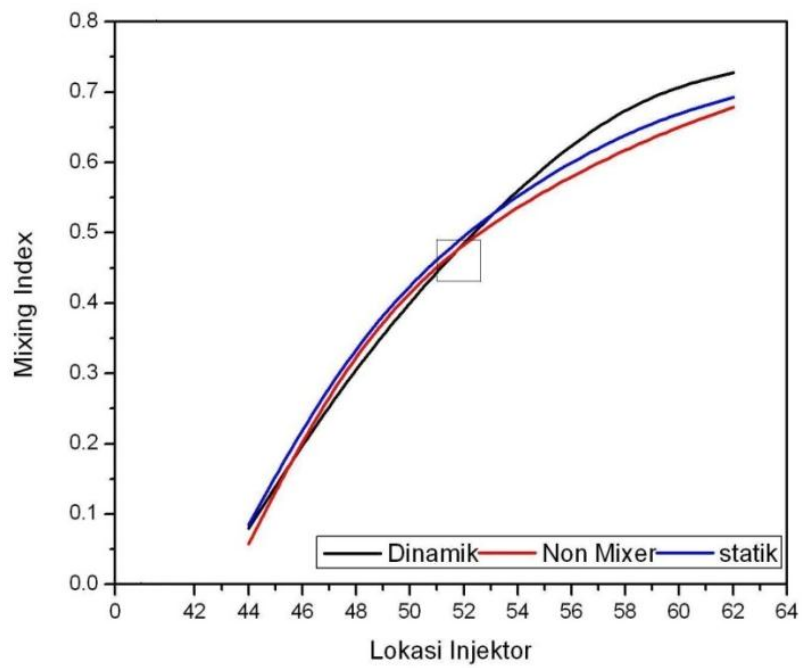

(d) GHSV 40.000

Gambar 6. Perbandingan indeks pencampuran (mixing index) antara sistem $\mathrm{NH}_{3}$-SCR yang menggunakan mixer dinamik, mixer statik dan yang tanpa menggunakan mixer untuk lokasi injektor yang berbeda pada berbagai variasi GHSV

Dari gambar ini dapat dinyatakan bahwa penggunaan mixer meningkatkan indeks pencampuran untuk injektor yang diletakkan di depan mixer untuk semua nilai GHSV. Sedangkan injektor yang diletakkan di belakang mixer, perubahan indeks pencampuran tidak tampak signifikan. Penggunaan mixer dinamik lebih efektif untuk meningkatkan indeks pencampuran dibandingkan dengan mixer statik dengan lokasi injektor di depan mixer.

\section{KESIMPULAN}

Karakteristik indeks pencampuran dengan lokasi injektor yang berbeda-beda telah diselesaikan deengan menggunakan pemodelan numerik. Penggunaan mixer dinamik mampu meningkatkan indeks pencampuran sampai $40 \%$ untuk injektor yang diletakkan di depan mixer pada jarak $8 \mathrm{~cm}$ dibandingkan dengan yang tanpa menggunakan mixer.

\section{REFERENSI}

[1] Anonymous, http://en.wikipedia.org/, diakses tanggal 20 Mei 2011.

[2] Anonymous, "Environmental Policy", http://newsbatch.com/environment.htm, diakses: 06 Januari 2015

[3] Andreas Hinz, Timothy Jarvis, Miroslawa A.M., Pascal A., Lennart A., Bengt O., Ronny A., Philip G. B., Mats L., Andrew P. W., James McGeehan, John W. G., Keith N. dan Klaus J. W., 2006, "Field Test Trucks Fulfilling EPA'07 Emission Levels On-Road by Utilizing the Combined DPF and Urea-SCR System," SAE International, 2006-01-0421.

[4] Joseph Theis dan Erdogan Gulari, 2006, "A LNT+SCR System for Treating the NOx Emissions from a Diesel Engine," SAE International, 2006-01-0210. 
[5] Hisakazu S. dan Hajime I., 2006, "Emission Characteristics of a Urea SCR System under Catalysts Activated and De-Activated Conditions," SAE International, 2006-01-0639.

[6] Mikael K., Ulf W., Sten F., Jonas J., Gert-Ove W., Christoph M. S., Christopher H. O. dan Lino G., 2006, “A Combined 3D/Lumped Modeling Approach to Ammonia SCR After-treatment System: Application to Mixer Designs," SAE International, 2006-01-0469.

[7] Felix B., Ulrich M., Peter W dan Olaf D, 2006, "analysis of the Injection of Urea-Water-Solution for Automotive SCR DeNOx-System: Modeling of Two-Phase Flow and Spray/Wall-Interaction," SAE International

[8] Xiaogang Zhang, Martin Rozek dan Chris Morgan, 2006, “3-D Numerical Study of Mixing Characteristics of $\mathrm{NH}_{3}$ in Front of SCR," SAE International, 2006-01-3444.

\section{UCAPAN TERIMA KASIH}

Penulis mengucapkan terimakasih kepada Jurusan Teknik Mesin Fakultas Teknik Universitas Diponegoro atas dukungan pendanaan yang diberikan pada penelitian ini. 